\title{
Article
}

http://dx.doi.org/10.11646/phytotaxa.204.2.1

\section{Taxonomic notes on Encephalartos ferox (Cycadales: Zamiaceae), with the description of a new subspecies from Mozambique}

\author{
PHILIP ROUSSEAU ${ }^{1 *}$, PIETER J. VORSTER ${ }^{2}$, ABILIO V. AFONSO ${ }^{3} \&$ ABRAHAM E. VAN WYK ${ }^{1}$ \\ ${ }^{1}$ H.G.W.J. Schweickerdt Herbarium, Department of Plant Science, University of Pretoria, Private Bag X20, 0028 Hatfield, Pretoria, \\ South Africa. \\ ${ }^{2}$ Department Botany and Zoology, University of Stellenbosch, South Africa, Private Bag X1, 7602 Matieland, Stellenbosch, South \\ Africa. \\ ${ }^{3}$ Instituto de Investigação Agrária de Moçambique, P.O. Box 3658, 1100 Maputo, Mozambique. \\ *Author for correspondence. E-mail: pr.philiprousseau@gmail.com
}

\begin{abstract}
Continued work on the systematics of the genus Encephalartos has been conducted over a large area along the Mozambican coast to determine the infraspecific variation and taxonomic status of Encephalartos ferox populations. The northern extent of the species was also investigated based on anecdotal information that it might represent a new taxon. Several (45) vegetative and reproductive (ca. 40) characters were analysed and used to re-circumscribe E. ferox. Literature and iconographic citations are included, as is information on ecology, cytology and conservation as available. No specimens of $E$. ferox were located north of the Save River in the Sofala Province, Mozambique, and the northernmost population of the species was found to be anomalous. Accordingly a new subspecies, E. ferox subsp. emersus, is recognised based on its invariably emergent stems, shorter unarmed petiole length, shorter leaves, greater number and narrower leaflets (in seedlings as well) which are more closely spaced. Strobili and peduncles in subsp. emersus are shorter and narrower with strobili having a propensity towards yellow, while internally the megasporophylls are green, grading to white away from the outer surface. The IUCN Red List status is suggested as Critically Endangered A4d + B1a,b(v) + B2a,b(v), with the threat of illegal over-collection highlighted.
\end{abstract}

\begin{abstract}
o
Estudos contínuos sobre a sistemática do gênero Encephalartos já foram realizados sobre uma grande área ao longo da costa de Moçambique para determinar variações infra-específicas e estado taxonômico das populações de Encephalartos ferox. A extensão da espécie no norte também foi investigada, baseado em evidência anedótica que a espécie pode representar um novo grupo taxonômico. Vários (45) caracteres vegetativos e reprodutivos (ca. 40) foram analisados e usados para circunscrever Encephalartos ferox. Literatura e citações iconográficas estão incluídas, também informações sobre a ecologia, citologia e conservação como disponível. Espécimenes de Encephalartos ferox não foram encontrados norte do rio Save, na província da Sofala e as populações mais setentrionais foram consideradas anômalas. Consequentemente, uma nova subespécie, Encephalartos ferox subsp. emersus é reconhecida. Com caules invariavelmente emergentes; pecíolos mais curtos e desarmados; folhas mais curtas e quantidade maior de folíolos mais estreitos (em mudas também) e estreitamente espaçados. Estróbilos e pedúnculos de Encephalartos ferox subsp. emersus são mais curtos e estreitos, com estróbilos mais propensos para o amarelo, enquanto megasporophylls são verdes internamente, tornando brancos distante da superfície externa. $\mathrm{O}$ estado da espécie sobre a Lista Vermelha da IUCN é Perigo Crítico A4D + B1a,b(v) + B2a,b(v), onde a ameaça de coleção ilegal é destacada.
\end{abstract}

Key words: cycad, Gymnosperm, taxonomy

\section{Introduction}

Taxonomy of the African endemic cycad genus Encephalartos Lehmann (1834: 1; Zamiaceae, Christenhusz et al. 2011), though remaining stable over the past two decades (Haynes 2012, Osborne et al. 2012), currently with 65 
species and two subspecies recognised, has suffered from several taxonomic uncertainties. An over-appreciation at the specific level as espoused by Dyer (1965a) and Vorster (2004), is due to their reluctance to recognise infraspecifc ranks, as robust phylogenies - revealing affinities - had yet to be constructed. Even molecular phylogenies remain unsettled (Van der Bank et al. 1998, 2001, Treutlein et al. 2005, Nagalingum 2011), though the latest efforts (Rousseau 2012) have resolved species groupings (2-7 taxa) with adequate support.

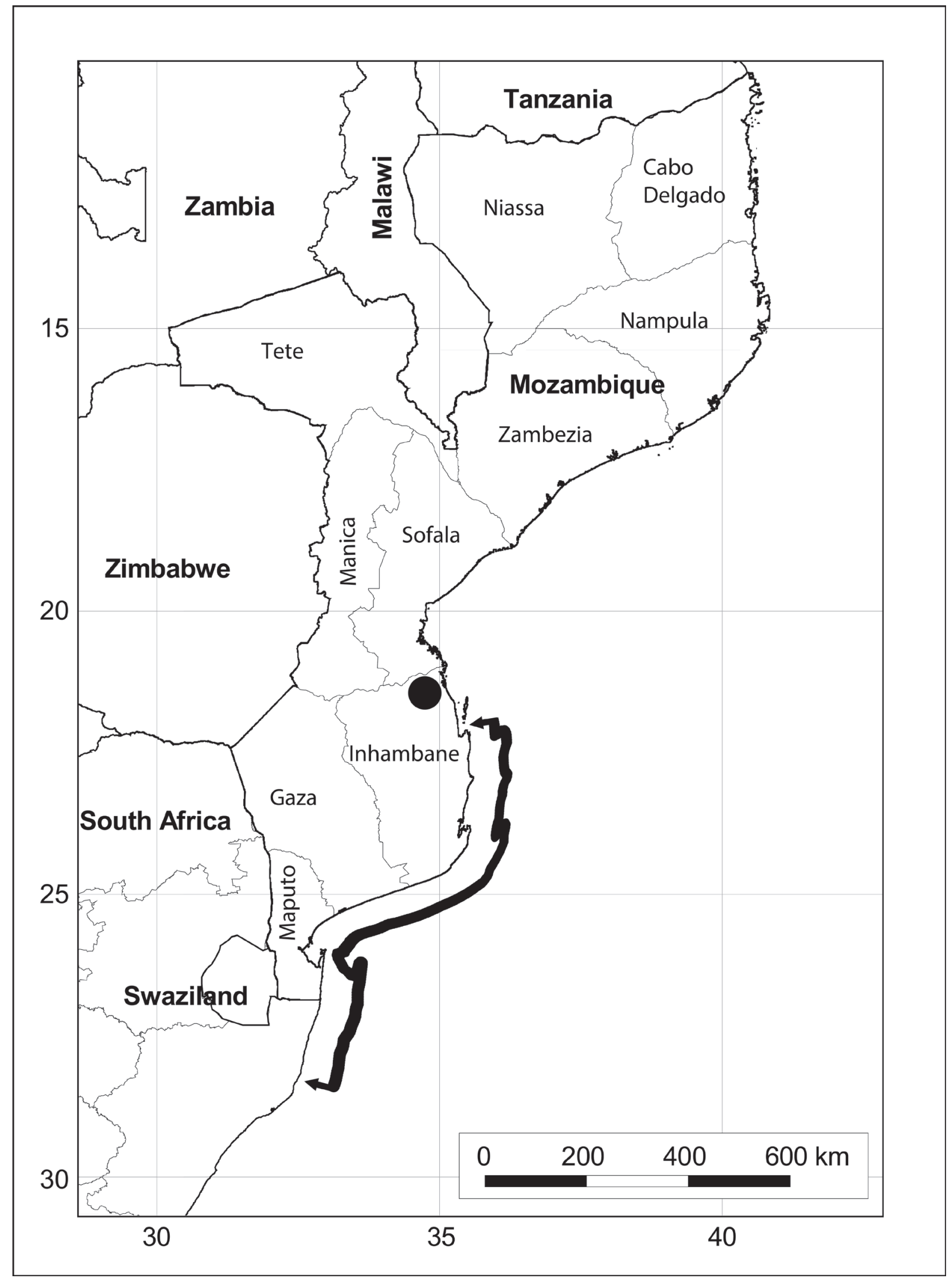

FIGURE 1. Known geographical distribution of Encephalartos ferox subsp. emersus (black dot). The thick black line mirrors the coastal range of E. ferox subsp. ferox, with arrows indicating its northern and southern limits. 
Hitherto taxonomic work on Encephalartos based solely on herbarium material has yielded less than ideal results, as such material lacks characters only discernible in living specimens (e.g. see the critiqued work of Schuster 1932). Field work is difficult because of the scarcity and remote location of species as well as the sporadic nature of reproductive events, which are of diagnostic value. Even in species as relatively widespread (Fig. 1) and common as Encephalartos ferox Bertoloni (1851: 264), in situ studies have focused predominantly on the more accessible populations at the southern limits of its distribution in South Africa (Dyer 1965a, Dyer \& Verdoorn 1966). Even Mozambican botanists have focused their efforts in and around Maputo (ex. Lourenço Marques), rarely venturing as far north as the Inhambane Province where the type is most probably from-as Bertoloni cites many of the other plants collected by Fornasini (the collector and artist for the type) from that area. Little or no formal work has been conducted towards the northern end of the species' range, with the distribution limits remaining speculative (Capela 2006, Donaldson 2010).

Most of the infraspecific variation exhibited by $E$. ferox is known informally among cycad enthusiasts based on cultivated material of unknown or doubtful origin (Whitelock 2002). Determining the prevalence of character states in an artificial setting is speculative with eventual generalisation on the species rooted in an incomplete understanding of such variation (Vorster 1993). In our continued work on the systematics of the genus, we here re-circumscribe E. ferox, and based on our observations, recognise a new subspecies that we name E. ferox subsp. emersus.

\section{Study area, materials and methods}

Fieldwork in Mozambique was conducted in the Gaza, Inhambane and Sofala provinces where populations were sampled every ca. $100 \mathrm{~km}$ along the coastline. Fieldwork could not be conducted in South Africa, as even though permits for the Isimangaliso Wetland Park were secured, the provincial authorities refused permission (though casual observations were made in habitat). All South African specimens cited are thus field accessioned cultivated plants. In total six distinct regions were sampled; individuals $n=59$. At each locality two to three individuals representing both sexes were sampled. As the northernmost taxa were anomalous, the sample size was increased to $n=41$ ( $n=19$ reproductive) and the nearest other population to $\mathrm{n}=7$. Each individual was analysed for 45 vegetative and, if reproducing, an additional ca. 40 fertile characters depending on sex and seed availability. Where applicable, nine measurements were made with three each direction: proximally, distally, and medially. In the morphological description of the taxa the arithmetic mean $(\bar{x})$ for diagnostic measurements appears in square brackets.

The area of occurrence for subsp. emersus was mapped by GPS. This subspecies is associated with distinct vegetated mounds (raised hillocks) emerging from the coastal plain (Fig. 2). Mapping was done by investigating all marginal mounds until two mounds in line were found devoid of individuals. This was then mapped onto Google Earth Pro where polygons were drawn to calculate the surface area. For area of occupancy all mounds of size more than 100 $\mathrm{m}^{2}$ were added. For population size several $(\mathrm{n}=10)$ mounds of intermittent size were counted for all mature individuals, the mean of which was used and multiplied by the number of mounds $>100 \mathrm{~m}^{2}$ in the area of occurrence.

The herbaria of LMA, LMU, PRE, and PRU were physically visited, while online access was made to K. The living collections of: the National Botanical Garden of Pretoria, Kirstenbosch and the Lowveld; Manie van der Schijff Botanical Garden (University of Pretoria); and numerous private collections were investigated. The descriptive terminology used follows Melville (1957) - except his sporophyll depth, which is here referred to as sporophyll length, and his sporophyll height, which has been modified to include the sporophyll stalk length; leaflet angles follow Grobbelaar (2002).

\section{Taxonomic treatment}

Encephalartos ferox Bertoloni (1851: 264). Type:-MOZAMBIQUE. Inhambane: at or near Inhambane, no date, ex Fornasini (K!, painting of holotype). (Figs 3-9)

Encephalartos kosiensis Hutchinson (1932: 512). Type:-SOUTH AFRICA. KwaZulu-Natal: East Ingwavuma District, no date, Aitken \& Gale 63, Kosi Bay, Col. Lugge in Natal Herb. 16507. Cultivated by Col. G. Molyneux at the “Old Fort” Durban, July 1930.

Habit subterranean (Fig. 3A) to emergent (Fig. 4A); rarely 1 to 4 basal offshoots with Donaldson (1998) stating plants in full sun are more prone to suckering; stems 500-1500 mm long, 200-400(-560) $\mathrm{mm}$ in diameter, lacking contractile 
tissue (Stevenson 1980); crown glabrous. Cataphylls similar between reproductive and vegetative structures, acuminate to linear, adaxially glabrous, white turning brown with age, abaxially with grey-brown to golden silky indumentum, $(35-) 40-111(-145) \times(4-) 10-20(-25) \mathrm{mm}$. Leaf base adaxially and abaxially ridged, collar absent, (15-)30-60 × (15-)30-60(80) $\mathrm{mm}$. Leaves (1060-)1280-2323(-2680) mm long, width distal (50-)105-160(-245) mm, proximal (60-)80-135(-180) $\mathrm{mm}$, median (140-)230-320(-350) $\mathrm{mm}$; rachis adaxially ridged to round in longitudinal section, glabrate green with white indumentum, straight to slightly arching, 25-42(50-60) $\mathrm{mm}$ in circumference; petiole with 2-12(-14) spines, unarmed petiole (0-)10-65(125-160) mm long. Leaflets (Fig. 5) broadly rectangular to ovate, colliculate, glossy bright to dark green (rarely brown on emergence), (25-)30-53 pairs, undulating transversely, curving abaxially at margins, pungent with (2-)3-6 distal, (0-)2-4 proximal margin teeth with crowding of 2 or 3 teeth at the apex, without overlap (rarely slightly succubous), length $\times$ width $\times$ spacing: distal $(80-) 100-145(-160) \times 15-35(-45) \times(10-) 15-35(-40) \mathrm{mm}$, proximal $(20-) 52-70(-100) \times(13-) 17-30(-38) \times(20-) 27-48(65-75) \mathrm{mm}$, median 100-193(-195) $\times(20-) 25-52(59-$ $65) \times(15-) 25-49(55-84) \mathrm{mm}, 16-43(-53)$ veins; pinna-pinna angle distal ca. $70-180^{\circ}$, proximal ca. $(90-) 150-180^{\circ}$, median ca. $(75-) 150-180^{\circ}$, pinna-rachis angle distal ca. $30-45(-75)^{\circ}$, proximal ca. $45-75^{\circ}$, median ca. $45(-75)^{\circ}$, swing angle distal ca. $0-15^{\circ}$, proximal ca. $0-35^{\circ}$, median ca. $0-15^{\circ}$. Micro- and megastrobili dissimilar. Microstrobili (Figs 3B, 6A, B) fusiform, red to orange or yellow, up to 5 produced successively, elongating from 150-235 mm to 320-500 (single strobilus measured at 960) $\mathrm{mm}$ long at maturity, 215-355 $\mathrm{mm}$ in circumference; peduncle (160-)200-370(-440) $\times 80-105(-180) \mathrm{mm}$; microsporophylls (Fig. 6C) rhomboid 4 to 5 facets, glabrous, length $\times$ width $\times$ height: distal 8-14 $\times 12-30 \times 20-35(-40) \mathrm{mm}$, proximal 6-15 × (12-)15-27(-35) $\times 16-35 \mathrm{~mm}$, median $(7-) 10-15 \times 20-32 \times 25-40(-44)$ $\mathrm{mm}$, central facet flat, distal (3-)4-11(-15) $\times(5-) 6-17 \mathrm{~mm}$, proximal 4-15 $\times 10-20 \mathrm{~mm}$, median (4-)5-8 $\times(7-) 9-16$ $\mathrm{mm}, 0(-4)$ sterile. Megastrobili (Figs 3C, D, 4B, 6C-E) ovoid to cylindrical, red to yellow, solitary (2, very rarely 3 ) produced simultaneously, $(285-) 300-510(-575) \times(490-) 575-705(-740) \mathrm{mm}$; peduncle $(60-) 85-135(-140) \times 125-219$ mm; megasporophylls (Fig. 7A-D) angular transversely obovate (rarely perfectly rhombic), 4 to 6 facets, glabrous, verrucose to rarely smooth, length $\times$ width $\times$ height: distal $(13-) 15-25(-30) \times(20-) 30-45(-50) \times(26-) 35-50(-62) \mathrm{mm}$, proximal 20-39(-45) $\times(20-) 35-55(-60) \times(20-) 42-64(-75) \mathrm{mm}$, median 20-37 $\times 35-57(-62) \times 58-87 \mathrm{~mm}$; central facet flush to slightly sunken, distal 7-15(-17) × 12-20 mm, proximal $(10-) 15-20 \times(12-) 17-25 \mathrm{~mm}$, median 8-14 $\times$ (10-)15-20 mm, stalk length distal 5-25 mm, proximal 26-38(-45) mm, median 38-57 mm, lateral lobe length distal 5-15(-17) mm, proximal 25-36(-47) $\mathrm{mm}$, median 27-60 $\mathrm{mm}$, sterile portion 70-120 mm long. Ovule sarcotesta white turning red at maturity; seeds 81 to 577 per strobilus (Phelan et al. 1993), cylindrical, 40-50 × 15-20(-32) mm (Dyer 1956a); kernel 9 to 20-grooved, 24-37 × 14-20 mm. Seedling leaves 86-145 mm long, unarmed petiole (53-)80-103 mm, leaflets 3-5 pairs, length $\times$ width $\times$ spacing: $(30-) 40-70(-80) \times 8-18 \times 5-12 \mathrm{~mm}$, with $6-14$ veins.

Taxonomic notes:-Encephalartos ferox is an enigmatic species in the genus with previous phylogenetic placement seeing much difference of opinion. In Osborne et al.'s phenetic analyses (1993) E. ferox was early divergent to all but one other Encephalartos species. Van der Bank et al. $(1998,2001)$ using isozymes found it early divergent to Eastern Cape (South Africa) species. Treutlein et al.'s (2005) molecular analysis of nuclear ITS positioned two replicates as unresolved (but monophyletic 92BP) in a clade of southern African species. Their morphological analysis grouped it with E. gratus Prain (1916: 181) (the only other species with red strobili) with weak support (59BP) (Treutlein et al. 2005). Rousseau (2012), using three plastid and one nuclear region, found numerous samples to group monophyletically with high support (93BP/1.0PP), though the backbone remains unresolved and as such the closest relative remains speculative—possibly an eastern seaboard South African subterranean-stemmed species (see: Rousseau 2012; Rousseau unpublished data).

Infraspecific variation:- Stems of up to two meters (Dyer 1956a) were not encountered and clearly were based on an anomalous specimen. Vegetative states that could not be confirmed from Dyer \& Verdoorn (1966) include an unarmed petiole of 240-300(-360) $\mathrm{mm}$, up to five teeth at leaflet apices that seems to be correlated with an increase in width with leaflets of up to $60-80 \mathrm{~mm}$, which is also unconfirmed in situ. The latter character state, often thought diagnostic for the species, seems confined to populations in the southernmost part of its distribution range. Reproductive states of up to 10 to 13 microstrobili (Donaldson 1998) and five or six megastrobili (Whitelock 2002) could not be confirmed and must constitute extreme rarities or a reflection of higher resources availability in cultivation. The prevalence of red strobili has been rejected in the case of males as the majority of microstrobili were orange, while megastrobili have very few exceptions ranging from orange to yellow. However, this should not be over-weighted as these simply represent a cline in pigmentation from red to yellow, although an allelic genetic component cannot be discounted with the current data. Studies to determine whether the colour of individual's strobili can change in situ or ex situ, are currently under way (Rousseau, unpublished data). The tendency for megastrobili to open in a single parted region (Fig. 3C) also seems to be a rarity rather than a diagnostic feature.

Although the southernmost populations have several distinguishing character states, the majority of character states are shared with other populations. Additionally no ecological separation occurs. As such the resurrection of the name $E$. kosiensis is not justified. However, as detailed fieldwork has not been conducted in the far southern parts of the species' range (following the expanded dataset and methodology), consistent diagnostic character states may yet be revealed. 

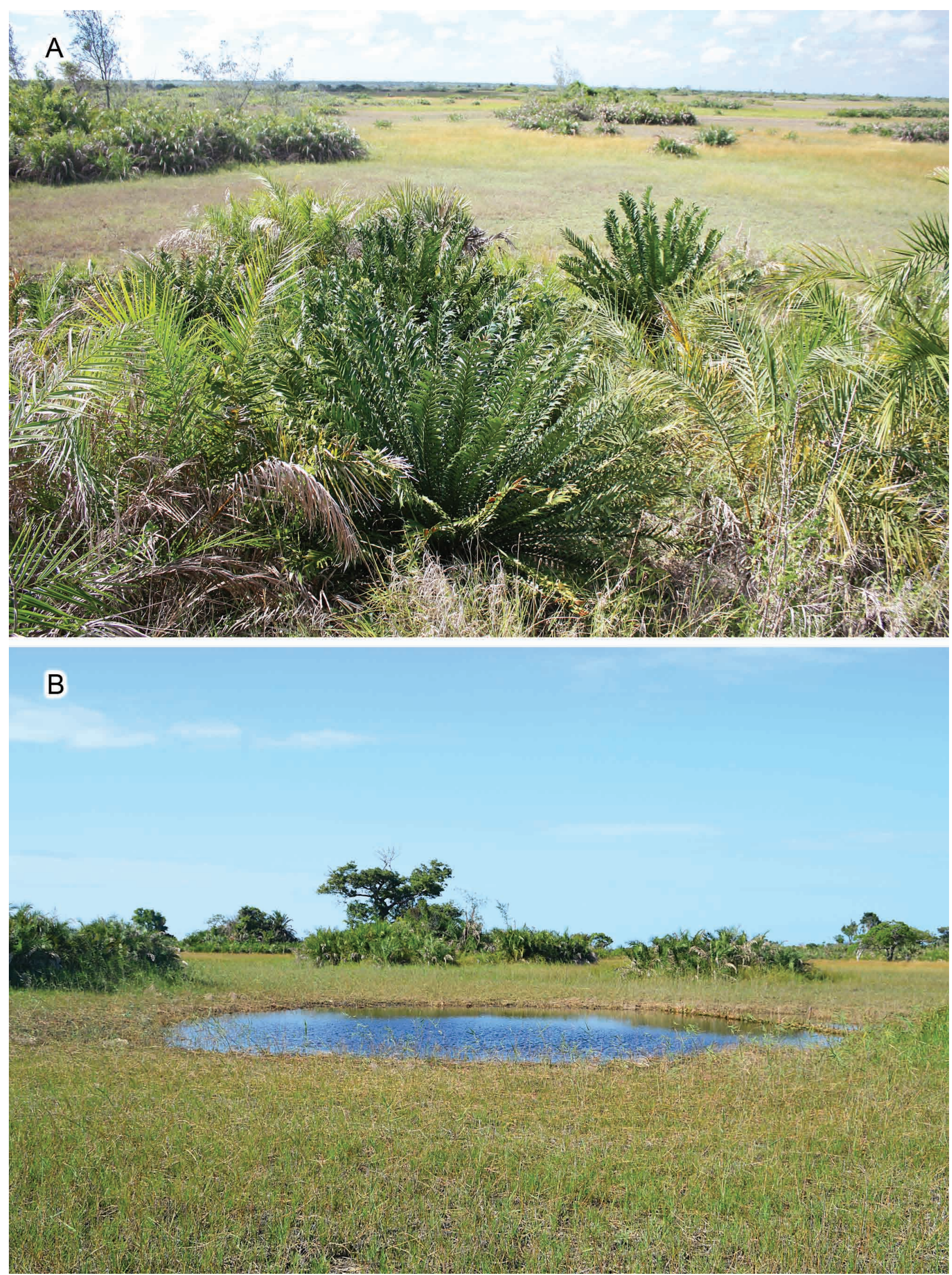

FIGURE 2. Encephalartos ferox subsp. emersus: habitat. A. Plants of subsp. emersus (in foreground) growing among the palm, Phoenix reclinata, on a raised mound (ancient termitarium); note surrounding low-lying floodplain with scattered raised mounds covered by woody vegetation. B. Floodplain with circular mounds covered by Phoenix reclinata and other woody plants, including our cycad. The permanently high water table is reflected by ponds (foreground) scattered throughout the area. Photographs: P. Rousseau (A), P.J. Vorster (B). 
No plants were located north of the Save River in Mozambique. The closest population to this geographic boundary between the Inhambane and Sofala provinces, is both ecologically and morphologically distinct. Moreover, the closest other $E$. ferox population is ca. $80 \mathrm{~km}$ further south, which represents a significant gap in a near-continues range of ca. $1000 \mathrm{~km}$, a discontinuity that is unusual in other members of Encephalartos. Hence this population is here recognised as a new subspecies.
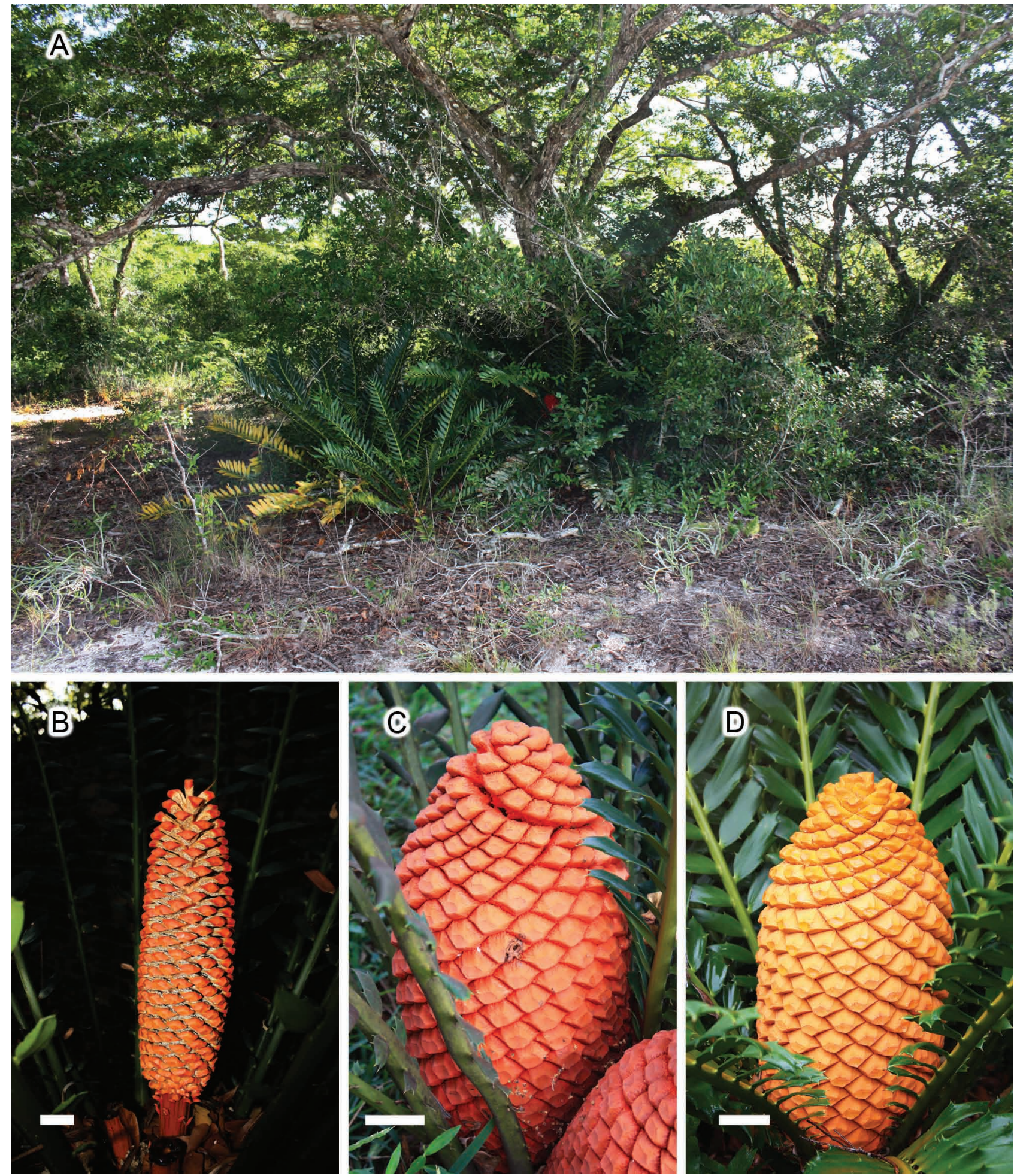

FIGURE 3. Encephalartos ferox subsp. ferox. A. Plants in habitat at its northernmost distribution; associated with forest on coastal dunes, often in the shade of taller trees and shrubs. B. Mature microstrobilus C. Receptive megastrobili. D. Megastrobilus; rare yellow form. Scale bars $=50$ mm. Vouchers: $\mathrm{B}=$ Rousseau 1046, C = Rousseau 1185. Photographs: P. Rousseau. 


\section{Key to the subspecies of Encephalartos ferox}

1. Stems subterranean (rarely emergent $>1 \mathrm{~m}$ ); median leaflet width 33-52(59-65 rarely up to 80) mm; median leaflet length $\times$ width ratio 3.3:1.0; strobili predominantly red to orange; megasporophylls concolourous externally and internally, red to rarely orange or yellow; seedling leaflet width 10-18 mm; ranging from northeastern KwaZulu-Natal (South Africa) to south of Vilanculos (Mozambique), associated with FZ Vegetation type 20: Miombo Woodlands on Lake Basin, Sul do Save Sands, Vegetation type 14b: Littoral dunes (Wild \& Barbosa 1968), and CB 1: Maputaland Coastal Belt (Mucina \& Rutherford 2006)...................... subsp. ferox Stems emergent, $1.0-1.5 \mathrm{~m}$ long above ground; median leaflet width (20-)25-34 mm; median leaflet length $\times$ width ratio 5:1; strobili predominantly yellow; megasporophylls discolourous, externally yellow, internally green grading to white away from the outer surface, rarely concolourous red; seedling leaflet width 8-13 mm; with a restricted range from north of Vilanculos to south of the Save River, associated with FZ Vegetation type 44 (Wild \& Barbosa 1968): Deciduous Tree Savanna with Palms (badly drained, lowland), confined to raised mounds (hillocks)....... subsp. emersus

\section{Encephalartos ferox subsp. ferox (Figs 3, 5A, B \& 7C, D)}

Literature citation (descriptions):-Prain (1917); Hutchinson \& Rattray (1933); Schuster (1932); Ogilvie (1939); Lewis (1960); Dyer (1965a); Dyer \& Verdoorn (1966); Giddy (1980); Osborne (1987); Goode (1989); Norstog \& Nicholls (1997); Heibloem (1999); Goode (2001); Grobbelaar (2002); Jones (2002); Whitelock (2002); Cooper \& Goode (2004).

Iconography citation:-Ogilvie (1939: 656): plate IV; Dyer (1965a: 500): figures 85-87; Lewis (1960: 80): table 1B; Dyer \& Verdoorn (1966: 27): figure 7; Osborne (1987: 14): front cover, figures 2-9; Giddy (1980: 111): plate 26.1-26.5; Goode (1989: 141): pp. 141143; Phelan et al. (1993: 11): figure 3; Nel (1993: 25): p. 25; Rautenbach (1995: 37): figure 1; Norstog \& Nicholls (1997: 130): colour figure 1, 35, 59; Heibloem (1999: 56): pp. 56-57; Claasen (1999: 18): front cover, colour figure 7; Henning (2000: 17): colour figure 6; Grobbelaar (2001: 13): colour figure 9; De Haas (2001: 18): colour figure 23; Goode (2001: 294): pp. 294-297; Grobbelaar (2002: 180): figures 6.13.1-6.13.4; Jones (2002: 264): p. 264; Whitelock (2002: 48): plate 262-265; Nel (2003: 25): figure 1, colour figures 26-31; Cooper \& Goode (2004: 73): plate 26; Surju (2005: 23): pp. 23-24; Steenkamp (2008: 38): p. 38; Hurter (2009: 35): figure 7; Retief (2009: 35): figure 8; Du Toit (2010: 40): p. 40; Tang (2011a: 21): figure 5; Tang (2011b: 26): figures 2-4, 7-12; Rousseau \& Mann (2012: 21): figures 1-7, 9-15; Rousseau (2013: 28): figure 3.

Stems subterranean, rarely emergent 150-1000 [300] mm long. Leaves (1060-)1280-2323(-2680) [1818] mm long; unarmed section of petiole (0-15-)30-65(75-160) [64] mm long with 2-4(-6) spines present. Median leaflets length $\times$ width $\times$ spacing: $(125-) 140-193$ [153] $\times 33-52(59-65)$ [46] ×32-49(55-84) [47] mm. Leaflet pairs (25-)30-37(45) [34], veins (27-)35-43(-53) [40]. Microstrobili predominantly orange to red very rarely yellow, length 320440(-960) [427] mm, circumference 260-355 [304] mm; peduncle length (160-)200-370(-440) [236] mm; median microsporophyll height (27-)32-40(-44) [35] mm. Megastrobili predominantly red, very rarely orange to yellow, length (300-)440-510(-575) [418] mm, circumference (490-)634-705(-740) [626] mm; peduncle length (65-)85$117(-140)$ [91] mm, circumference (141-)157-219 [177] mm; Median sporophyll height 62-87 [78]mm, sporophylls concolourous externally and internally. Seedling leaflet width 10-18 [15] $\mathrm{mm}$.

Habitat:-Encephalartos ferox subsp. ferox is near-endemic to the Maputaland Centre of Endemism (Van Wyk \& Smith 2001). It is found in Miombo Woodlands on Lake Basin and Sul do Save Sands (Fig. 3A), Brachystegia spiciformis Bentham (1866: 312) (Vegetation type 20, Wild \& Barbosa 1968) \& Littoral dunes, Mimusops caffra Meyer ex de Candolle (1844: 203) (Vegetation type 14b, Wild \& Barbosa 1968) and CB 1: Maputaland Coastal Belt (Mucina \& Rutherford 2006). Rainfall 1000-1250 mm per annum, elevation 20-100 m (Donaldson 2010).

Distribution:--SOUTH AFRICA: KwaZulu-Natal; MOZAMBIQUE: Maputo, Gaza, Inhambane. In South Africa it is only found in northeastern KwaZulu-Natal, the main distribution is in the province of Maputo, Gaza and Inhambane in Mozambique. It has not been located north of the Save River despite anecdotal claims by Capela (2006).

Taxonomic notes:-See Table 1.

Phenology:-Strobili found dehiscent/receptive (day/month): 23/03, 30/04; Inhambane, 29/04; Mapinhane, 29/04; Pomene, 30/4; Paindane, 01/05; Zavora, 02/05; Chidenguele; seed shedding around September.

Fauna:-Porthetes Schoenherr (1838: 1041) sp. nov. 7 (Oberprieler 1995, Downie et al. 2008) is known as probable pollinators, while a novel species of Erotylidae has been found here at all localities visited. The following Geomitridae (Lepidoptera, Staude 2001, Staude \& Sihvonen 2014) are also known to feed on the subspecies: Paraptychodes Warren (1894: 379) sp., Diptychis meraca Prout (1928: 19), Zerenopsis moi Staude \& Sihvonen (2014: 27), and Z. lepida Walker (1854: 571). Seed sarcotesta is routinely removed (consumed) though the agent(s) responsible are unknown. A 
seed dispersal agent seems absent as dispersal is very poor with many crowns littered with seed and even germinating seedlings.

Etymology:- Specific epithet from the Latin ferox = fierce, alluding to the large almost lobe-like leaflet teeth which are hard, stiff and sharp.

Representative specimens:-MOZAMBIQUE. Tofo: Rousseau \& Mann 26-28 (PRU), Mapinhane: Rousseau 1183B, Rousseau 1184 (PRU), Quewene/Belane: Rousseau 1257-1260 (PRU), Pomene: Rousseau 1185-1187 (PRU), Paindane: Rousseau 1188-1189(PRU), Zavora: Rousseau 1190-1191 (PRU), Chidenguele: Rousseau 1192-1193 (PRU), ex Xia Xia: Rousseau 1046 (PRU), Xai Xai: Jan de Koning 1.P1 (LMU), Chihanga: Maneul Fildalgo de Carvalho 1.281 (LMU), Pomene: Jan de Koning \& Daniel Zunguze 8971 (LMU), Inharrime: F. de Lemos \& A. Balsinhas 160 (LMA), Pomene: Jan de Koning \& F. Hiemstra 8971 (LMA), Vila de Joã Belo Praia de Sepuilveda: L.A. Grandvaux Barbosa \& F. de Lemos 8328 (LMA), Zavala: IIAM 9 (LMA), Chongoene: Ajuian Maan \& A. Baldjuihas $1107 A$ (LMA), Praia de Sepuilveda: J.G. Fedro 3463 (LMA), Chongoene: Pedro \& Pedrogão 1647 (LMA), Quissico: Pedro \& Pedrogão 1872 (LMA), Vila de Joã Belo: A.R. Torre 3879 (LMA). SOUTH AFRICA. KwaZulu-Natal: Rousseau 651 (JRAU), Rousseau 715 (JRAU), Rousseau 771 (JRAU), Rousseau 841 (Manie v/d Schijff \#4380, JRAU), Rousseau 844, Rousseau 993 (Manie v/d Schijff \#1452, JRAU), Rousseau 1013 (National Botanical Garden \#3130610, JRAU), Molyneux G s.n. Barcode \#000076187-000076188 (K).

Strobilus volatile chemistry:-Of the 19 Encephalartos taxa analysed by Suinyuy et al. (2013), E. ferox subsp. ferox was unique with a volatile composition dominated by alkanes (99\%).

Hybrids:-No natural hybrids are known as no other species of Encephalartos occur within the distribution range of E. ferox. Artificial hybridisation between E. ferox and other members of the genus-which generally hybridise easily with each other-has been mostly unsuccessful (Vorster, unpublished data). Known artificial hybrids (Vorster, unpublished data) have produced very low yields but include, E. ferox $\times$ E. woodii Sander (1908: 257), E. ferox $\times E$. trispinosus Dyer (1965b: 112), and E.ferox $\times$ E. caffer Thunberg (1775: 284) (see: Holzman 2005).

Conservation status:- Threats include removal for local and foreign horticulture, high burning frequency of grassland habitats kills seedlings and habitat is destroyed for coastal development and agriculture. Cousins et al. (2011) found ca. $10 \%$ of the Encephalartos material traded at the Warwick traditional medicinal market (Durban) to be $c f$. E. ferox where whole individuals are removed.
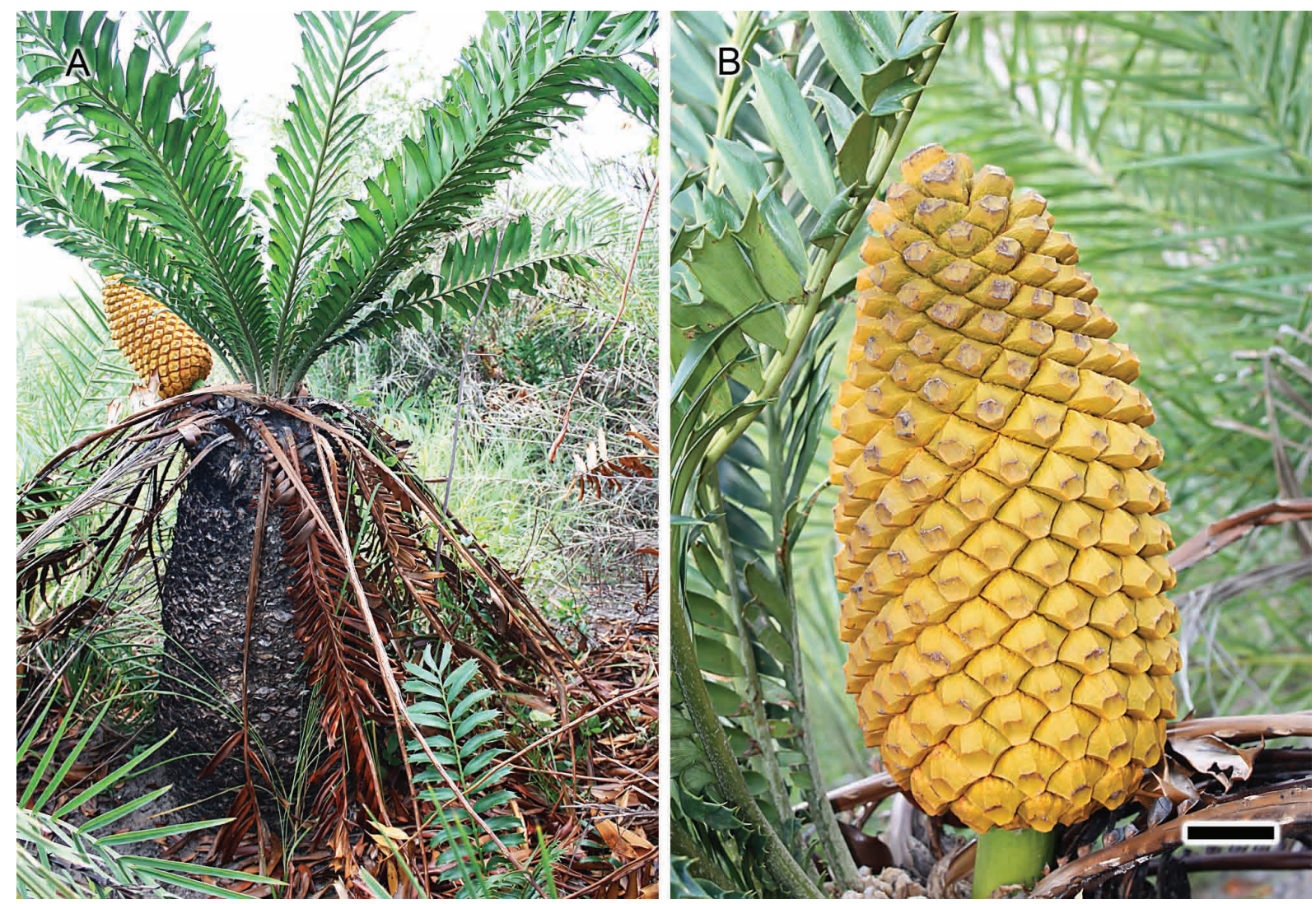

FIGURE 4. Encephalartos ferox subsp. emersus: female plant from which the herbarium material designated as type (Rousseau 1175) has been collected. A. Emergent plant habit; the distinctive trunk is ca. $1.5 \mathrm{~m}$ high. B. Megastrobilus; showing macromorphology. Scale bar $=60 \mathrm{~mm}$. Photographs: P. Rousseau. 
IUCN Red List status:- In 1997: Rare (Walter \& Gillett 1998), in 2003: Least Concern (IUCN 2003), in 2012: Near Threatened (Donaldson 2010). The suggested Red List categorisation is still at Near Threatened as the increased stability (at least in the southern parts) of Mozambique has seen a noticeable rise in the tourism in E.ferox habitats, which simultaneously destroys habitats and subsequently sources plants from other areas for cultivation.

TABLE 1. Comparison of subspecies of Encephalartos ferox. Arithmetic means $(\bar{x})$ in square brackets; all measurements in millimeters unless otherwise stated.

\begin{tabular}{|c|c|c|}
\hline Character & E. ferox subsp. ferox & E. ferox subsp. emersus \\
\hline \multirow[t]{5}{*}{ Habitat } & Coastal forest and thicket on littoral dunes; & Savanna-grassland with palms on poorly \\
\hline & miombo woodland on coastal sand; usually & drained riverine floodplain; plants restricted \\
\hline & in partial or complete shade & to raised mounds (termitaria) with woody \\
\hline & & vegetation in a hygrophilous grassland matrix; \\
\hline & & usually in full sun \\
\hline Stem habit & Subterranean to rarely emergent & Emergent \\
\hline Emergent stem length & Up to $1 \mathrm{~m}[300]$ & Over $1-1.5 \mathrm{~m}[716]$ \\
\hline Leaf length & Up to $2.6 \mathrm{~m}[1818]$ & Up to $2.35 \mathrm{~m}$ [1404] \\
\hline Petiole length (unarmed section) & $(0-15) 30-65(75-160)[64]$ & $(0-) 10-43(65-125)[23]$ \\
\hline Number of petiole spines & $2-4(-6)$ & $(6-) 8-12(-14)$ \\
\hline Median leaflet length & $(125-) 140-193$ [153] & $100-165(-195)[145]$ \\
\hline Median leaflet width & $33-52[46]$ & $(20-) 25-34[29]$ \\
\hline Median leaflet spacing & $32-49(55-84)[47]$ & $(15-) 25-36(-42)[25]$ \\
\hline Leaflet length/width ratio & $3.3: 1.0$ & $5.1: 1.0$ \\
\hline Leaflet length/width/spacing ratio & 3.28:0.99: 1.0 & 5.9:1.1: 1.0 \\
\hline Number of leaflet pairs & $(25-) 30-37(-45)[34]$ & $33-52[41]$ \\
\hline Number of veins/leaflet & $(27-) 35-43(-53)[40]$ & $(6-) 16-20(30-42)[24]$ \\
\hline Prevalent colour of strobili & Red to orange & Yellow \\
\hline Microstrobilus length & $320-440(-960)[427]$ & $430-500[340]$ \\
\hline Microstrobilus circumference & $260-355[304]$ & $215-310[257]$ \\
\hline Microstrobilus peduncle length & $(160-) 200-370(-440)[236]$ & $218-315$ [249] \\
\hline Microsporophyll median height & $(27-) 32-40(-44)[35]$ & $25-32(-43)[26]$ \\
\hline Megastrobilus length & $(300-) 440-510(-575)[418]$ & $(285-) 303-430(-480)[360]$ \\
\hline Megastrobilus circumference & $(490-) 634-705(-740)[626]$ & $(507-) 575-675(-729)[609]$ \\
\hline Megastrobilus peduncle length & $(65-) 85-117(-140)[91]$ & $60-135[85]$ \\
\hline Megastrobilus peduncle circumference & $(141-) 157-219$ [177] & $125-157(-180)[139]$ \\
\hline Megasporophyll external colour & Red & Yellow \\
\hline Megasporophyll internal colour & Red & $\begin{array}{l}\text { Green, grading to white away from the outer } \\
\text { surface }\end{array}$ \\
\hline Megasporophyll median height & $62-87[78]$ & $58-62[57]$ \\
\hline Seedling leaflet width & $10-18[15]$ & $8-13[10]$ \\
\hline
\end{tabular}

Encephalartos ferox subsp. emersus Rousseau, Vorster \& Van Wyk, subsp. nov. (Figs 4, 5C, 6, 7A, 7B, 8 \& 9)

Most similar to E. ferox subsp. ferox but distinguished (see Table 1) by its invariably emergent stems (Fig. 4A). Shorter unarmed section of the petiole (Fig. 7A), shorter leaves, narrower (Fig. 8B) and more closely spaced leaflets (Fig. 5C) present from the seedlings stage (Fig. 9I), with more leaflet pairs per leaf. Strobili and peduncles are smaller with a propensity for being yellow (Fig. 4B, 6A, D, E), while megasporophylls are discolourous, green internally when yellow externally (Fig. 7A). Vegetatively similar but reproductively dissimilar to E. hildebrandtii Braun \& Bouché (1874: 18) from northern Tanzania and southern Kenya (ca. $2000 \mathrm{~km}$ to the north), which is distinguished vegetatively by arborescent stems $(2.5-6 \mathrm{~m})$, longer leaves $(2-3 \mathrm{~m})$, relatively narrower leaflets $(80-350 \times$ 13-45 mm), which are more dentate with up to nine marginal teeth, leaflets not undulating transversely, and the unarmed petiole shorter $(10-70 \mathrm{~mm})$.

Type:-MOZAMBIQUE. Inhambane: [precise locality withheld], growing on an annual floodplain close to a river on a raised sand mound, -1 m, megastrobilus 26/04, Rousseau 1175 (holotype PRE, isotypes K, LMA, FTG, PRU [including liquid-preserved megasprophylls]). 
Habit emergent with stems 500-1500 [716] mm long. Leaf length (960-)1335-2080 [1404] mm; unarmed section of petiole length (0-)10-43(65-125) [23] mm, number of spines (6-)8-12(-14). Median leaflets length $\times$ width $\times$ spacing: 100-165(-195) [145] mm $\times(20-) 25-34$ [29] mm $\times(15-) 25-36(-42)$ [25] mm. Leaflet pairs 33-52 [41], veins 1620 (30-42) [24]. Microstrobili yellow, rarely orange, length 430-500 [340] mm, circumference 215-310 [257] mm; peduncle length 218-315 [249] mm; microsporophyll median height 25-32(-43) [26] mm. Megastrobili yellow, rarely red, length (285-)303-430(-480) [360] mm, circumference (507-)575-675(-729) [609] mm; peduncle length 60-135 [86] mm, peduncle circumference 125-157(-180) [139] mm; megasporophylls distinctly discolourous, yellow outside, green internally, median megasporophyll height 58-62 [57] mm. Seedling leaflet width 8-13 [10] $\mathrm{mm}$.
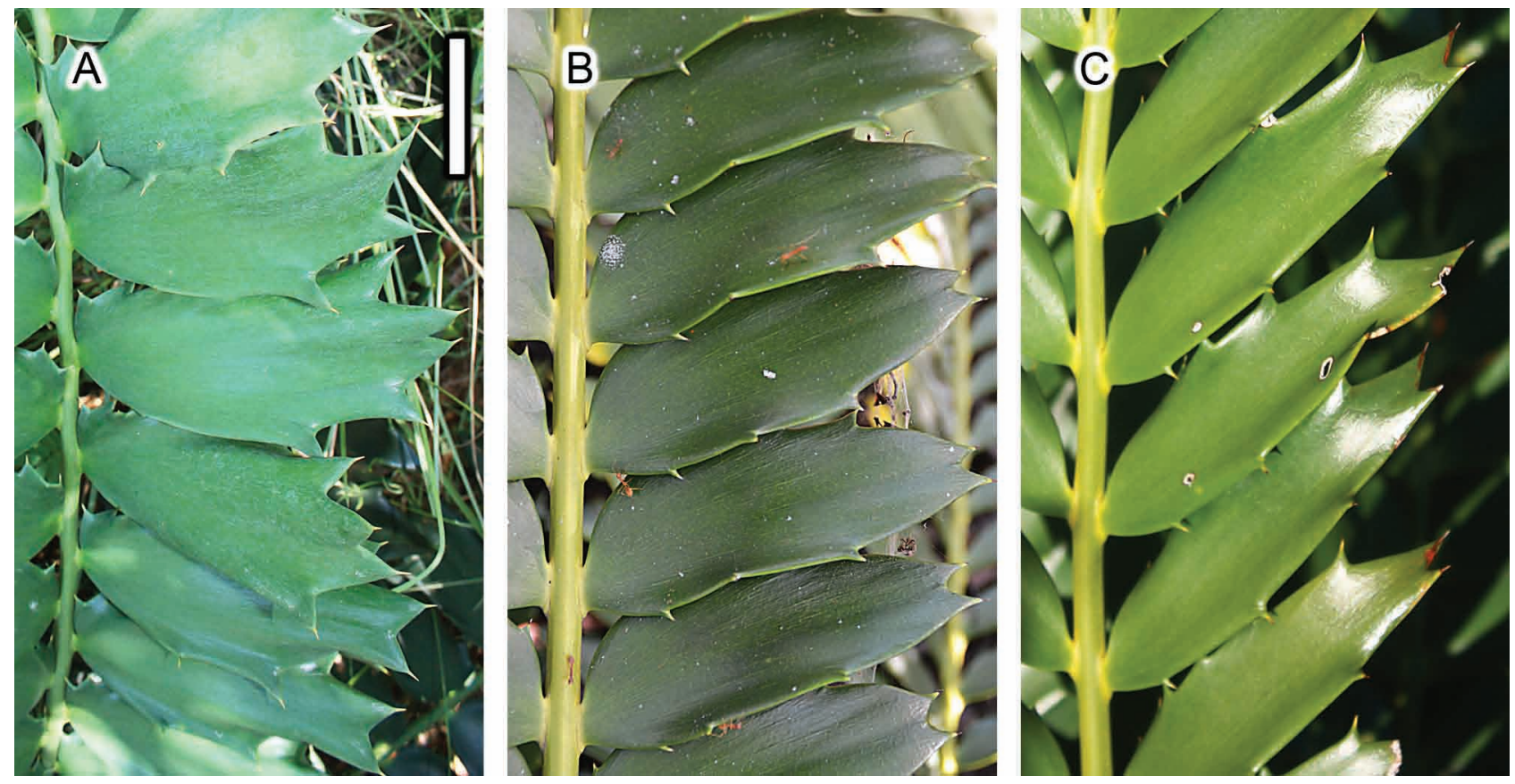

FIGURE 5. Encephalartos ferox: morphology of median leaflets. A. Subsp. ferox; from southernmost populations (=E. kosiensis). B. Subsp. ferox; from northernmost population. C. Subsp. emersus. Scale bar $=40 \mathrm{~mm}$. Photographs: P. Rousseau (A), P.J. Vorster (B \& C).

Distribution and habitat:- - This represents the most northerly distribution of the species, as fieldwork as far north as Baia de Sofala in Mozambique has not yielded any specimens. The subspecies is restricted to a single population consisting of two concentrations of individuals separated by ca. $1 \mathrm{~km}$, although the habitat is homogeneous. It is separated from the nearest population of E. ferox subsp. ferox to the south by ca. $80 \mathrm{~km}$ and E. hildebrandtii to the north by ca. $2000 \mathrm{~km}$. Encephalartos ferox subsp. emersus occurs in Vegetation type 44 (Wild \& Barbosa 1968), namely Deciduous Tree Savanna with Palms (badly drained lowland, Fig. 2). This vegetation type is found on poorly drained lowland, sublittoral zones as a result of water flowing from the undulation elevations of old quaternary dunes alternation with calcareous plains. Rainfall ca. $800 \mathrm{~mm}$ per annum. Outskirts are tree savanna dominated by Brachystegia spiciformis, and Pterocarpus angolensis de Candolle (1825: 419) amongst others. Floodplains are dominated by Phoenix reclinata Jacquin (1809: 27), Hyphaene crinita Gaertner (1790: 13), with pools and swamps interspersed, dominated by Phragmites communis Trinius (1822: 134), Nymphaea nouchali Burman (1768: 120), and Cyperus Linnaeus (1753: 44) species, while grasslands have irregular patches of several Paniceae and Andropogoneae grasses, with infrequent bare areas with Sarcocornia tegetaria Steffen, Mucina \& Kadereit (2009: 453). Encephalartos ferox subsp. emersus is restricted in this vegetation type to circular soil mounds (Fig. 2A) originating from giant termitaria (Complex 13 of Barbosa 1952) raised above the floodplain with its permanent ponds (Fig. 2B), with up to 20 individuals per mound. These mounds show clear successional vegetation patterns correlated with mound age and size starting with Phoenix reclinata and Hyphaene crinita, later including species such as a member of maculate Aloe Linnaeus (1753: 319), Erythrina humeana Sprengel (1826: 243), and finally large trees such as species of Euclea Linnaeus (1774: 747) and some of the adjacent savanna elements (Fig. 2B). Elevation -10-8 $\mathrm{m}$ with the soils grey and sandy.

Literature citation:- - Rousseau \& Mann (2012).

Iconography citation:- Rousseau \& Mann (2012: 25): figures 18-23.

Taxonomic notes:-See Table 1. In the diagnosis above, E. ferox subsp. emersus is also compared with $E$. hildebrandtii. This may raise the question whether our new taxon should not rather have been described as an infraspecific taxon of E. hildebrandtii. Is it not perhaps of hybrid origin, maybe even an allopolyploid involving E. ferox and $E$. 
hildebrandtii? Subsp. emersus is located about $2000 \mathrm{~km}$ south from the nearest known populations of $E$. hildebrandtii, thus genetic exchange between populations of E. ferox and E. hildebrandtii is highly unlikely, at least in relatively recent evolutionary times. This is supported as molecular evidence place E. ferox and E. hildebrandtii in different lineages (Treutlein et al. 2005, Rousseau 2012). Encephalartos ferox. subsp. ferox has proved very difficult to hybridise with other members of the genus (Vorster, unpublished data; though E. hildebrandtii has not been tested); we would suspect subsp. emersus to behave similarly. Hitherto polyploidy has not been reported in cycads (Gorelick \& Olson 2011), making an allopolyploid origin for subsp. emersus unlikely. The reasons for making the new taxon a subspecies of $E$. ferox is due to geographic proximity, and the considerable similarity in leaflet and cone morphology. Moreover, the red cones rarely encountered in subsp. emersus would support a close phylogenetic association with E. ferox and not E. hildebrandtii. We mainly make mention of the vegetative similarity with E. hildebrandtii to aid in ex situ identification where geographic data are absent.
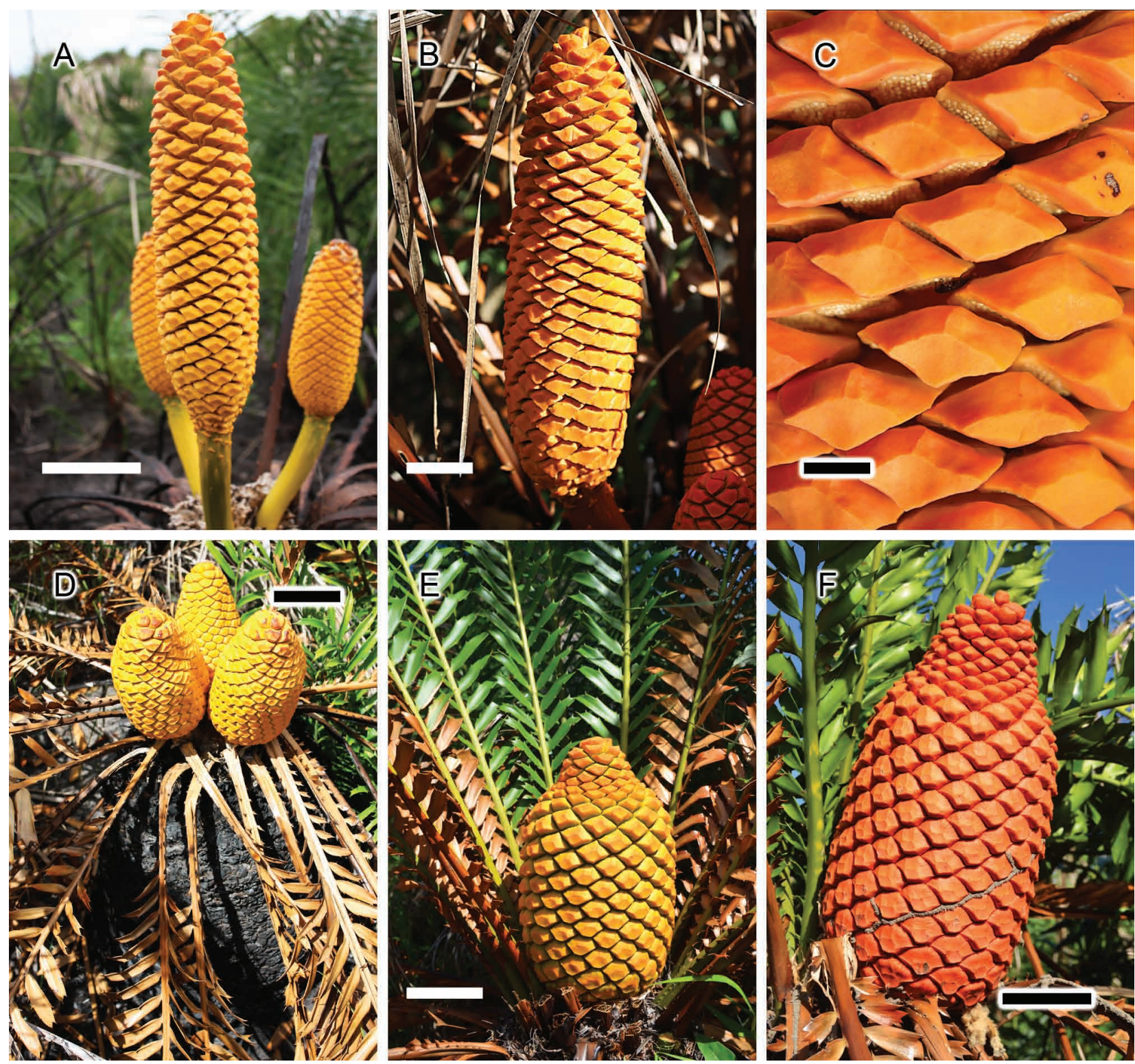

FIGURE 6. Encephalartos ferox subsp. emersus: variation in cone macromophology. A. Prevalent yellow microstrobilus, note successional maturation. B. Uncommon orange microstrobilus. C. Microsporophyll detail. D. Only instance of multiple megastrobili recorded. E. Prevalent yellow megastrobilus. F. Rare red megastrobilus. Scale bars: $A=80 \mathrm{~mm}, \mathrm{~B} \& \mathrm{C}=10 \mathrm{~mm}, \mathrm{D}=40 \mathrm{~mm}, \mathrm{E}=90 \mathrm{~mm}, \mathrm{~F}=100$ mm. Vouchers: $\mathrm{B}=$ Rousseau \& Mann 50, $\mathrm{C}=$ Rousseau 1130, D = Rousseau \& Mann 39, $\mathrm{E}=$ Rousseau 1252, $\mathrm{F}=$ Rousseau 1250. Photographs: P. Rousseau (A-D), P.J. Vorster (E \& F).

Phenology:-Strobili found dehiscent/receptive as early as (day/month): 28/02, 02/03, 13/03 with most strobili still immature, to $12 / 04$ with most of the colony mature, to as late as 27/04 where most of the microstrobili are spent. Seed dehiscence is still to be observed but speculated to be around September based on circumstantial evidence and interviews with local people. 
Fauna:- Two species of Coleoptera are associated with strobili during pollen shedding and are consistent with other pollinators of Encephalartos namely Porthetes sp. and a species of Erotylidae. Relationship with those found on E. ferox subsp. ferox has yet to be established. Damaged leaflets would also suggest the presence of Lepidoptera known to be associated with the genus. Seed coats are routinely eaten, most probably by birds and small mammals as is the case in the rest of the genus. Dispersal is very poor with many seeds never leaving the parental crown and thick stands germinating under parents.
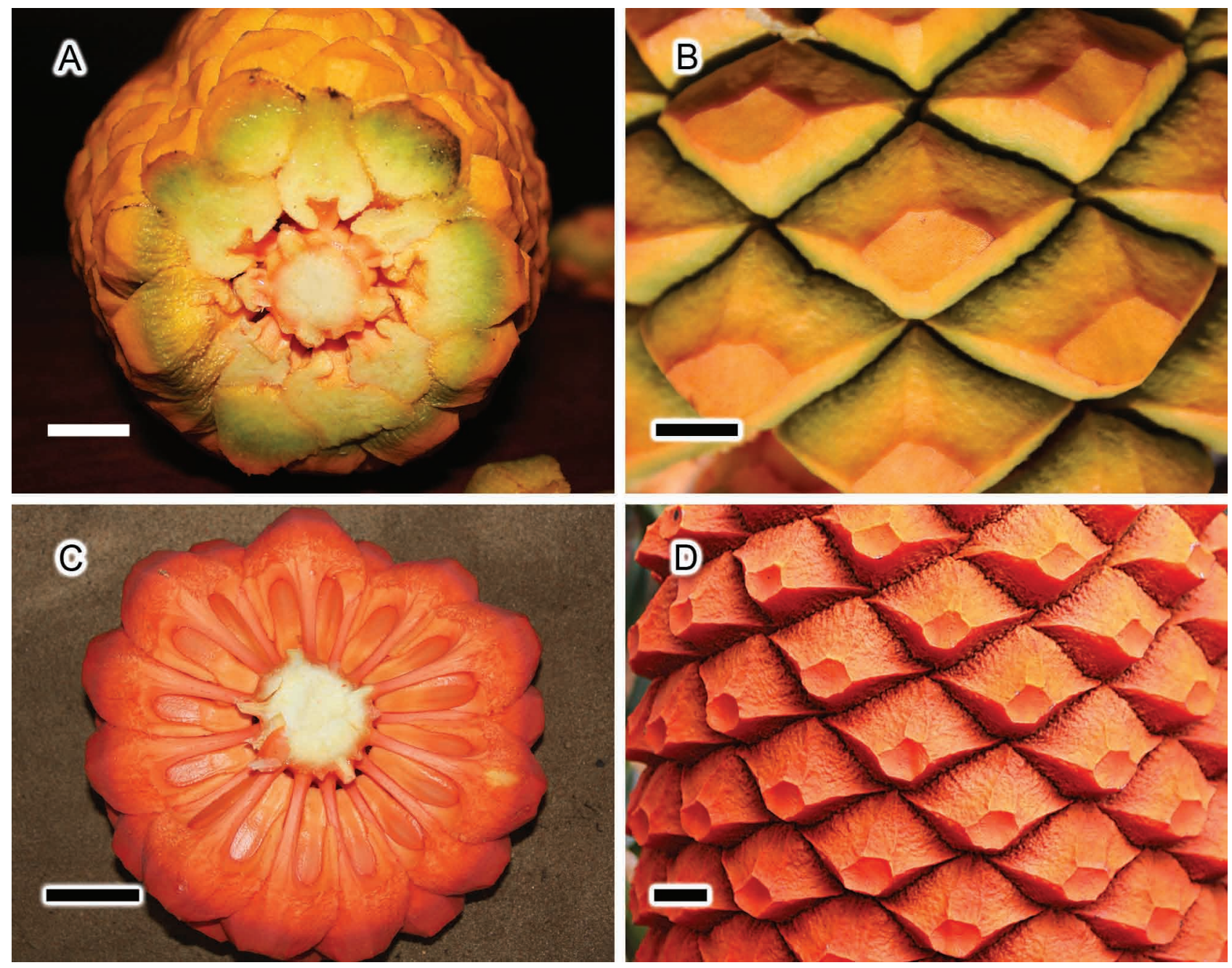

FIGURE 7. Encephalartos ferox: megasporophyll detail. A. Subsp. emersus; transverse section of megastrobilus with green internal tissue. B. Subsp. emersus; median megasporophyll outer surface detail. C. Subsp. ferox; transverse section of megastrobilus with red internal tissue. D. Subsp. ferox; median megasporophyll outer surface detail. Scale bars: A \& C = $30 \mathrm{~mm}, \mathrm{~B}=20 \mathrm{~mm}$. Vouchers: A= Rousseau \& Man 39, B = Rousseau 1252, C = Rousseau 1183B. Photographs: P. Rousseau.

Etymology:- Subspecific epithet derived from the Latin emersus, meaning "standing above" or "raised up", in reference-to the emergent stems as well as the vegetated soil mounds raised above the surrounding floodplains on which the plants grow.

Additional specimens examined (paratypes):-MOZAMBIQUE. Type locality: Rousseau \& Mann 29-32, Rousseau \& Mann 34-47, Rousseau \& Mann 50-55 (PRU), Rousseau 1130B (PRU), Rousseau 1175-1183 (PRU), Rousseau 1250-1256 (PRU).

Conservation status:- Subsp. emersus does not occur in a protected area and illegal collecting has increased over a three year survey period with some of the removed material traced back to the nearby town's tourist lodges. Large mature individuals are removed and seem to perform poorly in cultivation. The population size is estimated at 15 individuals per mound, with 70 mounds in the area of occurrence equaling $>1000$ mature individuals. Area of occurrence is $0.13 \mathrm{~km}^{2}$, area of occupancy is $0.05886 \mathrm{~km}^{2}$. As the subspecies occurs in a single locality where any stochastic event can eradicate the entire subspecies, and continued pressure from illegal collection is probable, we suggest the IUCN Red List rank of Critically Endangered A4d + B1a,b(v) + B2a,b(v). 


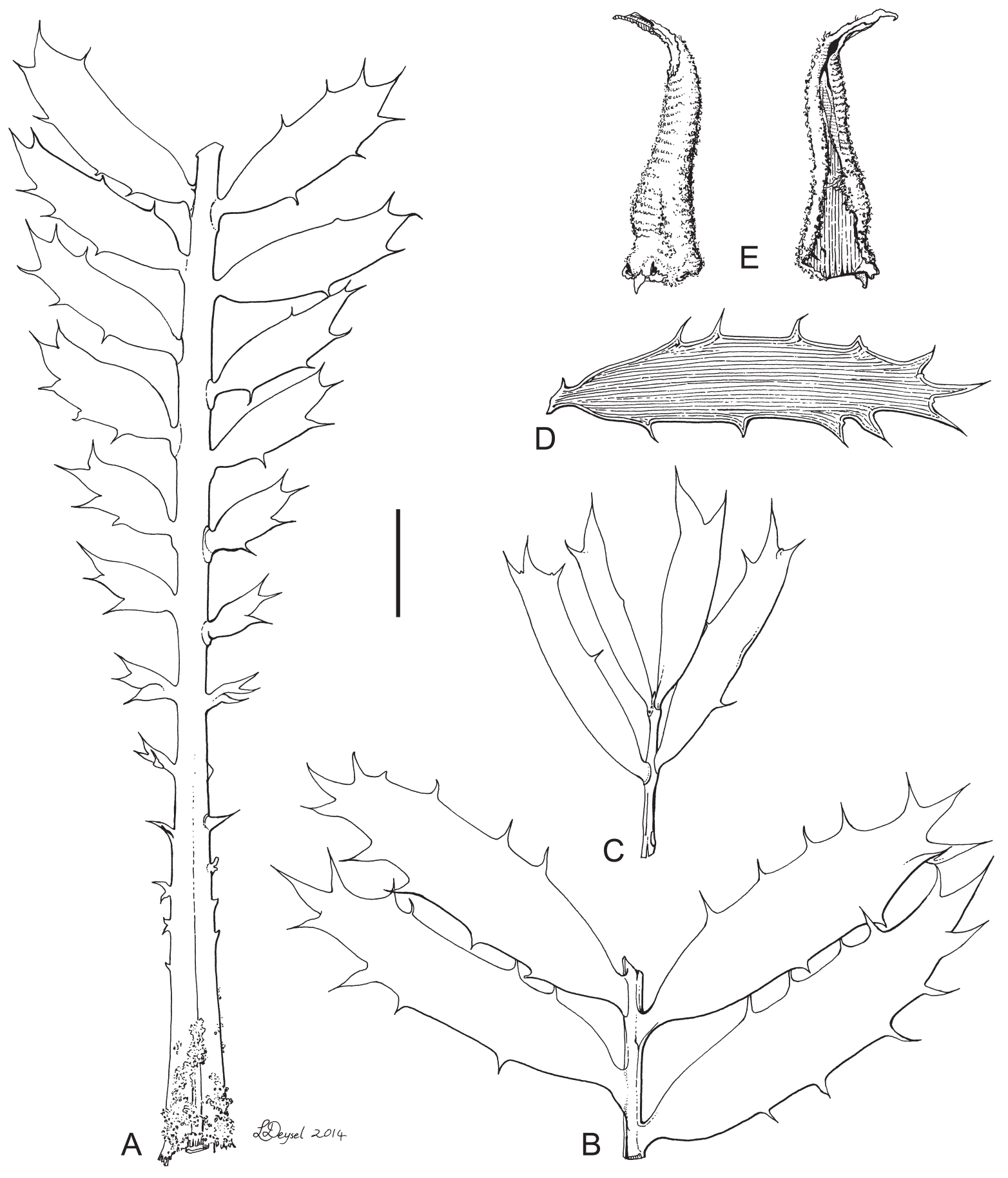

FIGURE 8. Encephalartos ferox subsp. emersus: vegetative morphology. A. Leaf; proximal portion. B. Leaf; median portion. C. Leaf; distal portion. D. Median leaflet; abaxial surface, showing distinct parallel venation. E. Cataphylls; adaxial (left) and abaxial (right) views. Scale bar $=40 \mathrm{~mm}$. Voucher: Rousseau 1175. Artist: Lesley Deysel.

\section{Acknowledgments}

We thank George Mann for help and companionship during field work, Sten Culverwell for assisting with local interviews, Marco de Canha for the Portuguese translation of the abstract, Hester Steyn for preparing the distribution map and Lesley Deysel for the line drawings. Our grateful thanks to Hermenegildo Matimele and Camila Sousa at the IIAM, Maputo, Mozambique, for plant collecting permits and logistical assistance. The Cycad Society of South Africa, University of Pretoria and the South African National Research Foundation are thanked for financial support. 


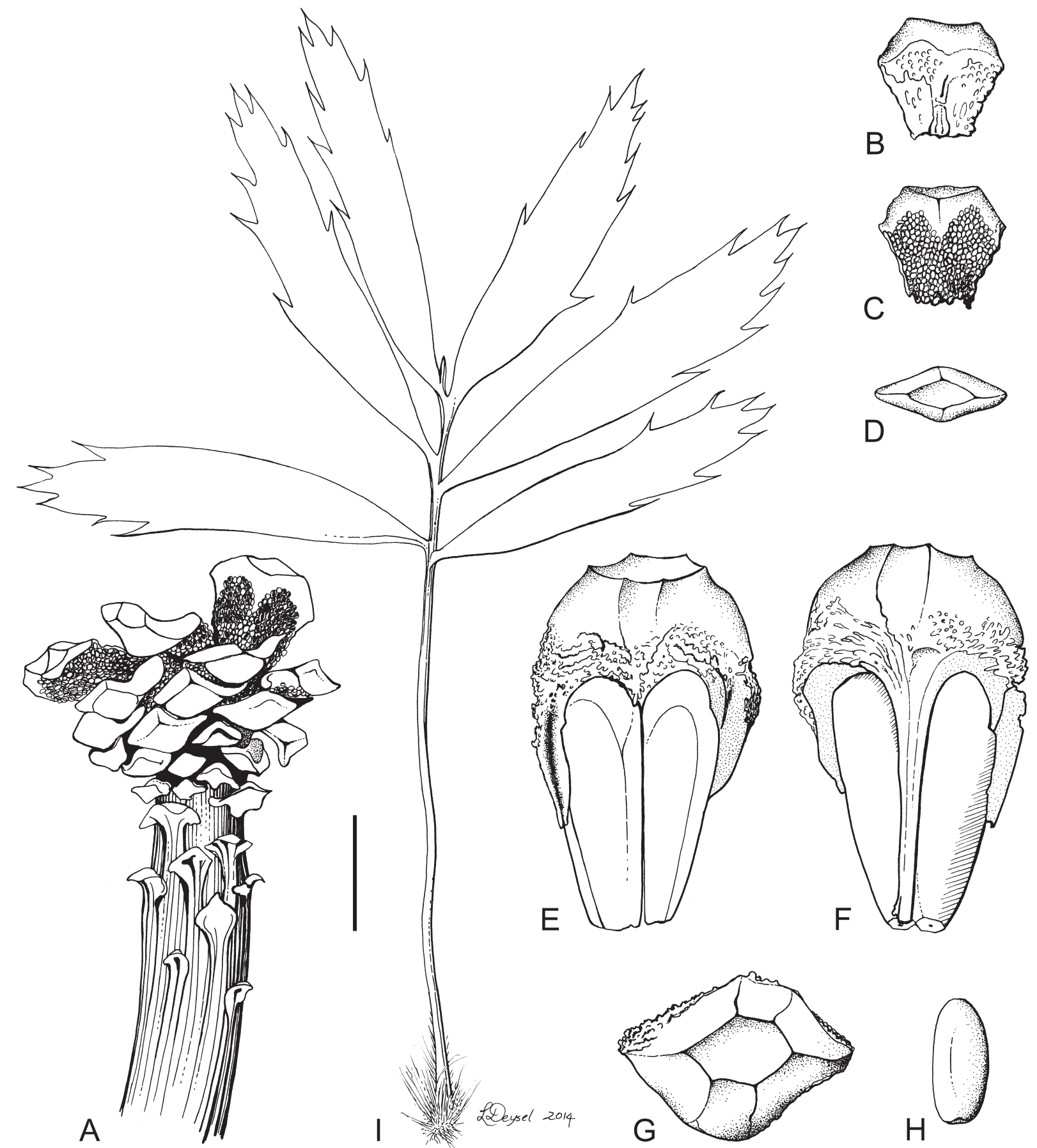

FIGURE 9. Encephalartos ferox subsp. emersus: reproductive morphology. A. Partial microstrobilus and peduncle; note basal reduced and sterile microsporophylls. B. Microsporophyll; adaxial view. C. Microsporophyll; abaxial view. D. Microsporophyll; distal (front) view. E. Megasporophyll with ovules; abaxial view. F. Megasporophyll with ovules; adaxial view. G. Megasporophyll; distal (front) view. H. Seed kernel with sarcotesta removed. I. Seedling leaf. Scale bar $=20 \mathrm{~mm}$. Voucher: Rousseau 1175. Artist: Lesley Deysel.

\section{References}

Barbosa, L.A.G. (1952) Esboço da vegetação da Zambézia. Separate from documentário Moçambique No. 69. Centro de Investigação Científica Algodoeira, Lourenço Marques, 38 pp.

Bentham, G. (1866) Description of some new genera and species of tropical Leguminosae. Transactions of the Linnean Society of London 25: $297-320$

http://dx.doi.org/10.1111/j.1096-3642.1865.tb00186.x 
Bertoloni, G. (1851) Illustrazione di plante Mozambicesi. Memorie della R. Accademia delle Scienze dell'Istituto di Bologna 3: 249-267. http://dx.doi.org/10.1007/bf03017533

Braun, A. \& Bouché, C.D. (1874) Plantae novae a cl. Hildebrandt ex Africa orientali allatae, a. 1874 in horto Berolinensi cultae. In: Braun, A., Koch, C., Ascherson, P. \& Bouché, C.D. (Eds.) Index seminum in Horto Botanico Berolinensi. C. Feister (L. Mewes), Berlin, pp. $1-18$.

Burman, N.L. (1768) Nicolai Laurentii Burmanni flora Indica: cui accedit series zoophytorum Indicorum, nec non prodromus florae Capensis. Haek, London, 292 pp. http://dx.doi.org/10.5962/bhl.title.60581

Capela, P. (2006) Speculations on the Encephalartos species of Mozambique. Published by the author, Chimoio, $131 \mathrm{pp}$.

Christenhusz, M.J.M., Reveal, J.L., Farjon, A., Gardner, M.F., Mill, R.P. \& Chase, M.W. (2011) A new classification and linear sequence of extant gymnosperms. Phytotaxa 19: 55-70.

Claasen, I. (1999) Miscellaneous figures. ENCEPHALARTOS 59: 18.

Cooper, M.R. \& Goode, D. (2004) The cycads \& cycads moths of KZN. Peroniceras Press, New Germany, 98 pp.

Cousins, S.R., Williams, V.L. \& Witkowski, E.T.F. (2011) Uncovering the cycad taxa (Encephalartos species) traded for traditional medicine in Johannesburg and Durban. South African Journal of Botany 78: 129-138. http://dx.doi:10.1016/j.sajb.2011.06.001

De Candolle, A.L.P.P. (1825) Prodromus systematis naturalis regni vegetabilis 2. Treuttel et Würtz, Paris, 644 pp. http://dx.doi.org/10.5962/bhl.title.286

De Candolle, A.L.P.P. (1844) Prodromus systematis naturalis regni vegetabilis 8. Fortin, Masson et Cie, Paris, 684 pp. http://dx.doi.org/10.1002/ardp.18440890229

De Haas, G. (2001) Miscellaneous figures. ENCEPHALARTOS 67: 18.

Donaldson, J. (1998) Life in the slow lane: the biology of cycad populations. ENCEPHALARTOS 56: 14-15.

Donaldson, J.S. (2010) Encephalartos ferox. The IUCN Red List of Threatened Species. Version 2014.1. Available from http://www. iucnredlist.org/details/41943/0 (accessed 21 July 2014).

Downie, D.A., Donaldson, J.S. \& Oberprieler, R.G. (2008) Molecular systematics and evolution in an African cycad-weevil interaction: Amorphocerini (Coleoptera: Curculionidae: Molytinae) weevils on Encephalartos. Molecular phylogenetics and evolution 47: 102116.

http://dx.doi.org/10.1016/j.ympev.2008.01.023

Du Toit, D. (2010) Letters to the editor. ENCEPHALARTOS 99: 40.

Dyer, R.A. (1965a) The cycads of southern Africa. Bothalia 8: 405-515.

Dyer, R.A. (1965b) New species and notes on type specimens of South African Encephalartos. Journal of South African Botany 31: 111-121.

Dyer, R.A. \& Verdoorn, I.C. (1966) Zamiaceae. In: Codd, L.E., De Winter, B. \& Rycroft, H.B. (Eds.) Flora of southern Africa. Cape and Transvaal printers limited, Pretoria, pp. 3-34.

Gaertner, J. (1790) De fructibus et seminibus plantarum 2. Schramm, London, 520 pp. http://dx.doi.org/10.5962/bhl.title.53838

Giddy, C. (1980) Cycads of South Africa, 2nd edition, 3rd impression. Purnell, Cape Town, 112 pp.

Goode, D. (1989) Cycads of Africa. Struik, Cape Town, 256 pp.

Goode, D. (2001) Cycads of Africa Volume I. Cycads of Africa Publishers, Gallo-manor, 352 pp.

Gorelick, R. \& Olson, K. (2011) Is lack of cycad (Cycadales) diversity a result of a lack of polyploidy? Botanical Journal of the Linnean Society 165: 156-167.

http://dx.doi:10.1111/j.1095-8339.2010.01103.x

Grobbelaar, N. (2001) Miscellaneous figures. ENCEPHALARTOS 66: 13.

Grobbelaar, N. (2002) Cycads-with special reference to the southern African species. Published by the author, Pretoria, $331 \mathrm{pp}$.

Haynes, J.L. (2012) World list of cycads: a historical review. IUCN/SSC Cycad Specialist Group. Available from: http://www.cycadsg. org/publications/Haynes-Historical-Review-of-World-List-of-Cycads-2012.pdf (accessed 21 July 2014).

Heibloem, P. (1999) Cycads of Central Africa: an introduction to the cycad species of the region. Publication fund of the Palm and Cycad Societies of Australia, Brisbane, $80 \mathrm{pp}$.

Henning, N. (2000) Miscellaneous figures. ENCEPHALARTOS 62: 17.

Holzman, G. (2005) Miscellaneous figures. ENCEPHALARTOS 83: 18.

Hurter, M. (2009) Miscellaneous figures. ENCEPHALARTOS 98: 35.

Hutchinson, J. (1932) Notes on the flora of southern Africa: III. Miscellaneous new species. Bulletin of Miscellaneous Information (Royal Gardens, Kew) 10: 510-512.

http://dx.doi.org/10.2307/4113428 
Hutchinson, J. \& Rattray, G. (1933) Cycadaceae. Flora capensis 5 (2): 24-44. http://dx.doi.org/10.1017/CBO9781107051324.022

IUCN (2003) Guidelines for application of IUCN Red List criteria at regional levels: version 3.0. IUCN Species Survival Commission. IUCN, Gland, Switzerland and Cambridge, UK, 26 pp.

Jacquin, N.J. (1809) Fragmenta botanica, figuris coloratis illustrata, ab anno 1800 ad annum 1809 per sex fasciculos edita, Fasciculus 1. Schmidt, Vienna, $138 \mathrm{pp}$. http://dx.doi.org/10.5962/bhl.title.538

Jones, D.L. (2002) Cycads of the world, ancient plants in today's landscape. New Holland Publishers, Sydney, $456 \mathrm{pp}$.

Lehmann, J.G.C. (1834) Novarum et minus cognitarum stirpium pugillus VI addita enumeratione plantarum omnium in his pugillis descriptarum. Meissner, Hamburg, 66 pp. http://dx.doi.org/10.5962/bhl.title.45011

Lewis, J. (1960) Cycadaceae. In: Exell, A.W. \& Wild, H. (Eds.) Flora zambesiaca. Crown agents for oversea governments and administrations, London, pp. 79-83.

Linnaeus, C. (1753) Species plantarum 1. Salvius, Stockholm, 560 pp. http://dx.doi.org/10.5962/bhl.title.37656

Linnaeus, C. (1774) Systema vegetabilium, secundum classes, ordines, genera, species, cum caracteribus et differentiis. Murray, Göttingen, $844 \mathrm{pp}$. http://dx.doi.org/10.5962/bhl.title.549

Melville, R. (1957) Encephalartos in Central Africa. Kew Bulletin 12: 237-257. http://dx.doi.org/10.2307/4114417

Mucina, L. \& Rutherford, M.C. (2006) The vegetation of South Africa, Lesotho, and Swaziland. Strelitzia 19, South African National Biodiversity Institute, Pretoria, $680 \mathrm{pp}$.

Nagalingum, N.S., Marshall, C.R., Quental, T.B., Rai, H.S., Little, D.P. \& Mathews, S. (2011) Recent synchronous radiation of a living fossil. Science 334: 796-799.

http://dx.doi:10.1126/science.1209926

Nel, D. (1993) The four-coned female Encephalartos ferox. ENCEPHALARTOS 35: 25.

Nel, D. (2003) Miscellaneous figures. ENCEPHALARTOS 76: 25.

Norstog, K.J. \& Nichols, T.J. (1997) The biology of the cycads. Cornell University Press, New York, 504 pp.

Oberprieler, R.G. (1995) The weevils (Coleoptera: Curculionidea) associated with the cycads. 1. Classification, relationships, and biology. In: Vorster, P. (Ed.) Proceedings of the 3rd International Conference on Cycad Biology. Cycad Society of South Africa, Stellenbosch, pp. 295-324.

Ogilvie, B.M.L. (1939) Some observations on Encephalartos kosiensis Hutch. Bulletin of Miscellaneous Information (Royal Gardens, Kew) 10: 655-657.

http://dx.doi.org/10.2307/4118177

Osborne, R. (1987) Focus on Encephalartos ferox. ENCEPHALARTOS 9: 14-21.

Osborne, R., Calonje, M.A., Hill, K.D., Stanberg, L. \& Stevenson, D.W. (2012) The world list of cycads. In: Stevenson, D.W., Osborne, R. $\&$ Blake, A.S.T. (Eds.) Proceedings of the 8th International Conference on Cycad Biology (CYCAD 2008), January 2008, Panama City, Panama. Memoirs of the New York Botanical Garden 106: 480-510.

Osborne, R., Grobbelaar, N. \& Vincent, P.L.D. (1993) A numerical phenetic study of the genus Encephalartos Lehm. In: Stevenson, D.W. \& Norstog, K.J. (Eds.) The biology, structure and systematics of the Cycadales. Proceedings of CYCAD 90, the 2nd International Conference on Cycad Biology. Palm and Cycad Societies of Australia, Milton, pp. 279-280.

Phelan, J., Van Hensbergen, H. \& Osborne, R. (1993) The apparent seed viability of Encephalartos ferox growing in sun and shade conditions in the wild. ENCEPHALARTOS 34: 11-14.

Prain, D. (1916) Diagnoses africanae: LXVIII. Bulletin of Miscellaneous Information (Royal Gardens, Kew) 7: 176-182. http://dx.doi.org/10.2307/4115074

Prain, D. (1917) Cycadaceae. Flora of tropical Africa 6 (2): 344-354.

Prout, L.B. (1928) Nouvelles Geometridae africaines de la collection Audeoud. Bulletin de la Société des Lépidoptéristes de Genève 6: 19-32.

Rautenbach, M. (1995) Encephalartos ferox frats? ENCEPHALARTOS 41: 37.

Retief, E. (2009) Miscellaneous figures. ENCEPHALARTOS 98: 35.

Rousseau, P. (2012) A molecular systematic study of the African endemic cycads. M.Sc. thesis, University of Johannesburg, Johannesburg, 176 pp. Available from: https://ujdigispace.uj.ac.za/handle/10210/5990 (accessed 2 December 2014).

Rousseau, P. (2013) Successive male cone production in Encephalartos. ENCEPHALARTOS 114: 27-32.

Rousseau, P. \& Mann, G.J. (2012) Visits to three Encephalartos ferox colonies: provisional impressions. ENCEPHALARTOS 109: 21-25.

Sander, M.F. (1908) New plants at Ghent. The Gardeners' Chronicle 43: 257-272. 
Schoenherr, C.J. (1838) Genera et species Curculionidum, cum synonymia hujus familae species novae 4 (2). Roret, Paris, 1148 pp. http://dx.doi.org/10.5962/bhl.title.8952

Schuster, J. (1932) Cycadaceae. In: Engler, A. (Ed.) Das Pflanzenreich 4, 99. Engelmann, Berlin, pp. 1-168.

Sprengel, K.P.J. (1826) Systema vegetabilium. Editio decima sexta volumen III. Dieterich, Göttingen, 936 pp. http://dx.doi.org/10.5962/bhl.title.822

Staude, H. (2001) African cycads and moths: An intricate relationship of ancient origin. In: Goode, D. (Ed.) Cycads of Africa Volume I. Cycads of Africa Publishers, Gallo-manor, pp. 307-311.

Staude, H.S. \& Sihvonen, P. (2014) Revision of the African geometrid genus Zerenopsis C. \&. R. Felder-moths with peculiar life histories and mating behaviours (Geometridae: Ennominae: Diptychini). METAMORPHOSIS Journal of the Lepidopterists'Society of Africa 25: 11-55.

Steenkamp, G. (2008) Letters to the editor. ENCEPHALARTOS 94: 38.

Steffen, S., Mucina, L. \& Kadereit, G. (2009) Three new species of Sarcocornia (Chenopodiaceae) from South Africa. Kew Bulletin 64: 447-459. http://dx.doi.org/10.1007/s12225-009-9127-1

Stevenson, D.W. (1980) Observations on root and stem contraction in cycads (Cycadales) with special reference to Zamia pumila L. Botanical Journal of the Linnean Society 81: 275-281. http://dx.doi.org/10.1111/j.1095-8339.1980.tb01678.x

Suinyuy, T.N., Donaldson, J.S. \& Johnson, S.D. (2013) Variation in the chemical composition of cone volatiles within the African cycad genus Encephalartos. Phytochemistry 85: 82-91.

http://dx.doi:10.1016/j.phytochem.2012.09.016

Surju, J. (2005) Letters to the editor. ENCEPHALARTOS 84: 23-24.

Tang, W. (2011a) Cold damage to cycad leaves. ENCEPHALARTOS 103: 20-22.

Tang, W. (2011b) Encephalartos ferox female cone: architecture and function. ENCEPHALARTOS 104: 25-29.

Thunberg, C.P. (1775) Cycas caffra, nova palmae species, descripta. Nova Acta regiae Societatis Scientiarum Upsaliensis 2: $283-288$.

Treutlein, J., Vorster, P. \& Wink, M. (2005) Molecular relationships in Encephalartos (Zamiaceae, Cycadales) based on nucleotide sequences of nuclear ITS 1, 2, rbcL, and genomic ISSR fingerprinting. Plant Biology 7: 1-12. http://dx.doi.org/10.1055/s-2004-830478

Trinius, C.B. (1822) Fundamenta agrostographiae, sive theoria constuctionis floris graminei; adjecta synopsi generum graminum hucusque cognitorum. Heubner, Vienna, 214 pp. http://dx.doi.org/10.5962/bhl.title.15521

Van der Bank, F.H., Vorster, P., Van der Bank, M. \& Wink, M. (1998) Phylogeny of Encephalartos: some Eastern Cape species. The Botanical Review 70: 250-259. http://dx.doi.org/10.1663/0006-8101(2004)070[0250:poesec]2.0.co;2

Van der Bank, F.H., Wink, M., Vorster, P., Treutlein, J., Brand, L., Van der bank, M. \& Hurter, J. (2001) Allozyme and DNA sequence comparisons of nine species of Encephalartos (Zamiaceae). Biochemical Systematics and Ecology 29: 241-266. http://dx.doi.org/10.1016/s0305-1978(00)00064-8

Van Wyk, A.E. \& Smith, G.F. (2001) Regions of floristic endemism in southern Africa: a review with emphasis on succulents. Umdaus Press, Pretoria, 199 pp.

Vorster, P. (1993) Taxonomy of Encephalartos (Zamiaceae): taxonomically useful external characteristics. In: Stevenson, D.W. \& Norstog, K.J. (Eds.) Proceedings of Cycad 90, the 2nd International Conference on Cycad Biology. Palm and Cycad Societies of Australia, Milton, pp. 294-299.

Vorster, P. (2004) Chapter 6: Classification concepts in Encephalartos (Zamiaceae). In: Walters, T. \& Osborne, R. (Eds.) Cycad classification: concepts and recommendations. CABI Publishing, Wallingford, pp. 69-83. http://dx.doi.org/10.1079/9780851997414.0069

Walker, F. (1854) List of the specimens of Lepidopterous insects in the collection of the British Museum. Part 2. Lepidoptera, Heterocera: 280-581. British Museum (Natural History), Department of Zoology, London. http://dx.doi.org/10.5962/bhl.title.58221

Walter, K.S. \& Gillett, H.J. (1998) 1997 lUCN Red List of Threatened Plants. Compiled by the World Conservation Monitoring Centre, IUCN-The World Conservation Union, Gland, Switzerland and Cambridge, $862 \mathrm{pp}$.

Warren, W. (1894) New genera and species of Geometridae. Novitates Zoologicae 1: 366-466.

Whitelock, L.M. (2002) The Cycads. Timber Press, Oregon, 374 pp.

Wild, H. \& Barbosa, L.A.G. (1968) Vegetation map of the Flora zambesiaca area. Supplement of Flora zambesiaca. Collins, Salisbury, $71 \mathrm{pp}$. 